\title{
Syntheses, Crystal Structures, and Antibacterial Activity of New Tetranuclear Zinc(II) Complexes with Schiff Base Ligands
}

\author{
Heng-Yu Qian \\ Key Laboratory of Surface \& Interface Science of Henan, School of Material \& Chemical Engineering, \\ Zhengzhou University of Light Industry, Zhengzhou, 450002 P.R. China \\ *Corresponding author: E-mail: hengyu_qian@126.com
}

Received: 01-08-2021

\begin{abstract}
Two new tetranuclear zinc(II) complexes, $\left[\mathrm{Zn}_{4}\left(\mathrm{~L}^{1}\right)_{2}\left(\mu_{2}-\eta^{1}: \eta^{1}-\mathrm{CH}_{3} \mathrm{COO}\right)_{4}\left(\mu_{1,1}-\mathrm{N}_{3}\right)_{2}\right]$ (1) and $\left[\mathrm{Zn}_{4}\left(\mathrm{~L}^{2}\right)_{4}\left(\mathrm{CH}_{3} \mathrm{CH}_{2} \mathrm{OH}\right)\right.$ $\left(\mathrm{H}_{2} \mathrm{O}\right)$ ] (2), where $\mathrm{L}^{1}$ and $\mathrm{L}^{2}$ are the deprotonated forms of 4-fluoro-2-((pyridin-2-ylmethylimino)methyl)phenol ( $\left.\mathrm{HL}^{1}\right)$ and 4-fluoro-2-((2-(hydroxymethyl)phenylimino)methyl)phenol $\left(\mathrm{H}_{2} \mathrm{~L}^{2}\right)$, have been synthesized and characterized by elemental analysis, IR and UV-vis spectroscopy, and single crystal X-ray diffraction. X-ray crystal structural study indicated that the distances between the adjacent $Z n$ atoms are 3.160(1)-3.353(1) $\AA$ in 1 and 3.005(1)-3.168(1) $\AA$ in 2 . All zinc atoms in $\mathbf{1}$ are pentacoordinated in trigonal bipyramidal geometry, and those in $\mathbf{2}$ are in square pyramidal and octahedral geometry. The complexes and the Schiff bases were assayed for antibacterial activities against three Gram-positive bacterial strains (B. subtilis, S. aureus, and St. faecalis) and three Gram-negative bacterial strains (E. coli, P. aeruginosa, and E. cloacae) by MTT method.
\end{abstract}

Keywords: Tridentate Schiff base; crystal structure; zinc complex; tetranuclear structure; antibacterial property

\section{Introduction}

Zinc is an important element for biological processes of human beings. ${ }^{1}$ However, the mechanism of action of zinc in physiology and pathology are poorly understood. Zinc is also an essential cofactor in six classes of enzymes as well as in several families of regulatory proteins. ${ }^{2}$ Its importance in DNA synthesis, control of gene expression, and induction of cell apoptosis is becoming better understood. ${ }^{3}$ Schiff bases derived from substituted salicylaldehyde with various organic amines are important ligands in coordination chemistry, ${ }^{4}$ and show various biological properties such as antitumor, ${ }^{5}$ antibacterial, ${ }^{6}$ anti-fungi, ${ }^{7}$ and enzyme inhibition. ${ }^{8}$ It was reported that the compounds containing one or more halo-atoms on the aromatic ring have improved biological properties, especially for the antibacterial activities. ${ }^{9}$ Rai et al. reported a series of fluoro, chloro, bromo and iodo-substituted compounds, and found that they have significant antimicrobial activities. ${ }^{10}$ Acetate, azide anions and the phenolate group of Schiff base ligands usually act as flexible bridging ligands, which bind different metal atoms to form interesting polymeric structures. ${ }^{11}$ In the present work, two new tetranu- clear $\quad \operatorname{zinc}(\mathrm{II}) \quad$ complexes, $\quad\left[\mathrm{Zn}_{4}\left(\mathrm{~L}^{1}\right)_{2}\left(\mu_{2}-\eta^{1}: \eta^{1}-\right.\right.$ $\left.\left.\mathrm{CH}_{3} \mathrm{COO}\right)_{4}\left(\mu_{1,1}-\mathrm{N}_{3}\right)_{2}\right]$ (1) and $\left[\mathrm{Zn}_{4}\left(\mathrm{~L}^{2}\right)_{4}\left(\mathrm{CH}_{3} \mathrm{CH}_{2} \mathrm{OH}\right)\right.$ $\left.\left(\mathrm{H}_{2} \mathrm{O}\right)\right](2)$, where $\mathrm{L}^{1}$ and $\mathrm{L}^{2}$ are the deprotonated forms of 4-fluoro-2-((pyridin-2-ylmethylimino)methyl)phenol (HL ${ }^{1}$; Scheme 1, left) and 4-fluoro-2-((2-(hydroxymethyl) phenylimino)methyl)phenol $\left(\mathrm{H}_{2} \mathrm{~L}^{2}\right.$; Scheme 1, right), is reported.<smiles>Oc1ccc(F)cc1/C=N/Cc1ccccn1</smiles><smiles>OCc1ccccc1/N=C/c1cc(F)ccc1O</smiles>

Scheme 1. The Schiff base ligands.

\section{Experimental}

\section{1. Material and Measurements}

All chemical reagents and solvents were of analytical grade and were obtained from Sigma-Aldrich. Elemental analyses were performed on a Perkin-Elmer 2400 II elemental analyzer. Infrared spectra were recorded on a Per- 
kin-Elmer RX I FT-IR spectrophotometer with $\mathrm{KBr}$ discs. Electronic spectra were obtained with Lambda 35 spectrophotometer.

\section{2. Synthesis of the Schiff Bases}

The Schiff bases $\mathrm{HL}^{1}$ and $\mathrm{H}_{2} \mathrm{~L}^{2}$ were synthesized by refluxing hot ethanolic solution $(30 \mathrm{~mL})$ of 5-fluorosalicylaldehyde $(0.002 \mathrm{~mol}, 0.280 \mathrm{~g})$ with 2-aminomethylpyridine $(0.002 \mathrm{~mol}, 0.216 \mathrm{~g})$ and 2-aminophenylmethanol, respectively, for $1 \mathrm{~h}$. The precipitate formed during reflux was filtered, washed with cold $\mathrm{EtOH}$, and recrystallized from hot $\mathrm{EtOH}$.

$\mathrm{HL}^{1}$ : Yield 77\%. Anal. Calcd. for $\mathrm{C}_{13} \mathrm{H}_{11} \mathrm{FN}_{2} \mathrm{O}$ : C 67.82, H 4.82, N 12.17. Found: C 67.71, H 4.93, N 12.26. IR data $\left(\mathrm{KBr}, \mathrm{cm}^{-1}\right): 3327,1622,1585,1571,1513,1473,1438$, $1389,1346,1285,1220,1205,1153,1140,1112,1034,960$, $877,830,797,762,723,710,633,620$. UV-Vis data in ethanol $\left[\lambda_{\max }(\mathrm{nm}), \varepsilon\left(\mathrm{L} \mathrm{mol}^{-1} \mathrm{~cm}^{-1}\right)\right]: 250,14570 ; 280,17530$; 300, 18150; 380, 7637.

$\mathrm{H}_{2} \mathrm{~L}^{2}$ : Yield 83\%. Anal. Calcd. for $\mathrm{C}_{14} \mathrm{H}_{12} \mathrm{FNO}_{2}$ : C 68.56, H 4.93, N 5.71. Found: C 68.67, H 5.02, N 5.63. IR data $\left(\mathrm{KBr}, \mathrm{cm}^{-1}\right): 3341,3243,1626,1570,1485,1447,1387$, 1355, 1321, 1257, 1201, 1141, 1103, 1034, 955, 870, 795, 767, $716,667,626,575,535,466$. UV-Vis data in ethanol $\left[\lambda_{\max }\right.$ $\left.(\mathrm{nm}), \varepsilon\left(\mathrm{L} \mathrm{mol}^{-1} \mathrm{~cm}^{-1}\right)\right]: 230,19310 ; 265,14220 ; 347,13150$.

\section{3. Synthesis of the $\mathrm{Zn}$ (II) Complex 1}

An ethanolic solution $(20 \mathrm{~mL})$ of $\mathrm{HL}^{1}(0.20 \mathrm{mmol}$, $0.046 \mathrm{~g})$ was mixed with an ethanolic solution $(30 \mathrm{~mL})$ of $\mathrm{Zn}\left(\mathrm{CH}_{3} \mathrm{COO}\right)_{2} \cdot 2 \mathrm{H}_{2} \mathrm{O}(0.50 \mathrm{mmol}, 0.11 \mathrm{~g})$ and an aqueous solution $(1 \mathrm{~mL})$ of sodium azide $(0.20 \mathrm{mmol}, 0.013 \mathrm{~g})$, and refluxed in a water bath for $1 \mathrm{~h}$. The separated complex was filtered, washed thoroughly with water, ethanol, ether, and finally dried in a vacuum over fused $\mathrm{CaCl}_{2}$. Yield $56 \%$. Anal. Calcd. for $\mathrm{C}_{34} \mathrm{H}_{32} \mathrm{~F}_{2} \mathrm{~N}_{10} \mathrm{O}_{10} \mathrm{Zn}_{4}$ : C 39.26, H 3.10, N 13.46. Found: C 39.05, H 3.18, N 13.33. IR data $\left(\mathrm{KBr}, \mathrm{cm}^{-}\right.$ $\left.{ }^{1}\right): 2080,1640,1598,1480,1437,1395,1289,1213,1154$, $1044,874,815,769,667,617,561,490,456$. UV-Vis data in ethanol $\left[\lambda_{\max }(\mathrm{nm}), \varepsilon\left(\mathrm{L} \mathrm{mol}^{-1} \mathrm{~cm}^{-1}\right)\right]: 232,19150 ; 250$, $18110 ; 280,12560 ; 370,5570$.

A small amount of the complex was recrystallized from ethanol, affording colorless single crystals suitable for X-ray analysis.

\section{4. Synthesis of the $\mathrm{Zn}$ (II) Complex 2}

An ethanolic solution $(20 \mathrm{~mL})$ of $\mathrm{H}_{2} \mathrm{~L}^{2}(0.20 \mathrm{mmol}$, $0.049 \mathrm{~g})$ was mixed with an ethanolic solution $(30 \mathrm{~mL})$ of $\mathrm{Zn}\left(\mathrm{CH}_{3} \mathrm{COO}\right)_{2} \cdot 2 \mathrm{H}_{2} \mathrm{O}(0.50 \mathrm{mmol}, 110 \mathrm{mg})$ and refluxed in a water bath for $1 \mathrm{~h}$. The separated complex was filtered, washed thoroughly with water, ethanol, ether, and finally dried in a vacuum over fused $\mathrm{CaCl}_{2}$. Yield $43 \%$. Anal. Calcd. for $\mathrm{C}_{58} \mathrm{H}_{48} \mathrm{~F}_{4} \mathrm{~N}_{4} \mathrm{O}_{10} \mathrm{Zn}_{4}$ : C 53.64, H 3.73, N 4.31. Found: C 53.45, H 3.91, N 4.25. IR data $\left(\mathrm{KBr}, \mathrm{cm}^{-1}\right): 3641,1609,1536$,
$1460,1382,1306,1241,1198,1139,1026,979,874,816,752$, $673,624,564,513,443$. UV-Vis data in ethanol $\left[\lambda_{\max }(\mathrm{nm})\right.$, $\left.\varepsilon\left(\mathrm{L} \mathrm{mol}^{-1} \mathrm{~cm}^{-1}\right)\right]: 238,17270 ; 281,11450 ; 399,8760$.

A small amount of the complex was recrystallized from ethanol, affording colorless single crystals suitable for X-ray analysis.

\section{5. Single Crystal X-Ray Diffraction}

$\mathrm{X}$-ray data for the complexes were collected on a Bruker APEX II diffractometer equipped with graphite-monochromated Mo $K \alpha$ radiation $(\lambda=0.71073 \AA)$. A preliminary orientation matrix and cell parameters were determined from three sets of $\omega$ scans at different starting angles. Data frames were obtained at scan intervals of $0.5^{\circ}$ with an exposure time of $10 \mathrm{~s}$ frame $\mathrm{e}^{-1}$. The reflection data were corrected for Lorentz and polarization factors. Absorption corrections were carried out using SADABS. The structures of the complexes were solved by direct method and refined by full-matrix least-squares analysis using anisotropic thermal parameters for non- $\mathrm{H}$ atoms with the SHELXTL. ${ }^{12}$ All $\mathrm{H}$ atoms were calculated at idealized positions and refined with the riding models. Crystallographic data for the complexes are summarized in Table 1.

Table 1. Crystal and refinement data for the complexes

\begin{tabular}{|c|c|c|}
\hline Parameter & 1 & 2 \\
\hline Empirical formula $\mathrm{C}_{3}$ & $\mathrm{C}_{34} \mathrm{H}_{32} \mathrm{~F}_{2} \mathrm{~N}_{10} \mathrm{O}_{10} \mathrm{Zn}_{4}$ & $\mathrm{C}_{58} \mathrm{H}_{48} \mathrm{~F}_{4} \mathrm{~N}_{4} \mathrm{O}_{10} \mathrm{Zn}_{4}$ \\
\hline Formula weight & 1040.2 & 1298.5 \\
\hline Crystal size (mm) & $0.20 \times 0.20 \times 0.15$ & $0.16 \times 0.15 \times 0.15$ \\
\hline Temperature $\left({ }^{\circ} \mathrm{C}\right)$ & $298(2)$ & $298(2)$ \\
\hline Wavelength $(\AA)$ & 0.71073 & 0.71073 \\
\hline Crystal system & triclinic & triclinic \\
\hline Space group & $P \overline{1}$ & $P \overline{1}$ \\
\hline$a(\AA)$ & $8.4606(9)$ & $14.0120(11)$ \\
\hline$b(\AA)$ & $10.8780(11)$ & $14.1500(10)$ \\
\hline$c(\AA)$ & $11.0332(11)$ & $15.1470(10)$ \\
\hline$\alpha\left({ }^{\circ}\right)$ & $84.734(2)$ & $101.189(1)$ \\
\hline$\beta\left({ }^{\circ}\right)$ & $86.041(2)$ & $103.022(1)$ \\
\hline $\mathrm{g}\left({ }^{\circ}\right)$ & $88.243(2)$ & $93.211(1)$ \\
\hline $\mathrm{V}\left(\AA^{3}\right)$ & $1008.43(18)$ & $2854.7(4)$ \\
\hline $\mathrm{Z}$ & 1 & 2 \\
\hline$D_{\text {calc }}\left(\mathrm{g} \mathrm{cm}^{-3}\right)$ & 1.713 & 1.511 \\
\hline$\mu(\operatorname{Mo~K} \alpha)\left(\mathrm{mm}^{-1}\right)$ & 2.427 & 1.734 \\
\hline$F(000)$ & 524 & 1320 \\
\hline $\begin{array}{l}\text { Number of measured } \\
\text { reflections }\end{array}$ & 9913 & 15426 \\
\hline $\begin{array}{l}\text { Number of observation } \\
\quad(I>2 \sigma(I))\end{array}$ & 3748 & 9251 \\
\hline Unique reflections & 3175 & 5361 \\
\hline Parameters & 273 & 722 \\
\hline Number of restraints & 0 & 0 \\
\hline$R_{1}, w R_{2}(I>2 \sigma(I))^{\mathrm{a}}$ & $0.0273,0.0641$ & $0.0640,0.1841$ \\
\hline$R_{1}, w R_{2}(\text { all data })^{\mathrm{a}}$ & $0.0360,0.0687$ & $0.1182,0.2252$ \\
\hline Goodness of fit of $F^{2}$ & 1.034 & 1.013 \\
\hline
\end{tabular}




\section{5. Antibacterial Activity}

Antibacterial activity of the Schiff base ligands and the complexes was tested against $B$. subtilis, $S$. aureus, $S$. faecalis, $P$. aeruginosa, E. coli, and E. cloacae using MTT medium. The minimum inhibitory concentrations (MICs) of the compounds were determined by a colorimetric method using MTT dye. ${ }^{13}$ A stock solution of the compounds $\left(50 \mu \mathrm{g} \mathrm{mL}^{-1}\right)$ in DMSO was prepared and quantities of the compounds were incorporated in specified quantity of sterilized liquid medium. A specified quantity of the medium containing the compounds was poured into micro-titration plates. Suspension of the microorganism was prepared to contain approximately $10^{5} \mathrm{cfu} \mathrm{mL}^{-1}$ and applied to micro-titration plates with serially diluted compounds in DMSO to be tested, and incubated at $37^{\circ} \mathrm{C}$ for $24 \mathrm{~h}$ for bacteria. After the MICs were visually determined on each micro-titration plate, $50 \mu \mathrm{L}$ of phosphate buffered saline (PBS $0.01 \mathrm{~mol} \mathrm{~L}-1, \mathrm{pH} 7.4: \mathrm{Na}_{2} \mathrm{HPO}_{4} \cdot 12 \mathrm{H}_{2} \mathrm{O}$ $2.9 \mathrm{~g}, \mathrm{KH}_{2} \mathrm{PO}_{4} 0.2 \mathrm{~g}, \mathrm{NaCl} 8.0 \mathrm{~g}, \mathrm{KCl} 0.2 \mathrm{~g}$, distilled water $1000 \mathrm{~mL}$ ) containing $2 \mathrm{mg} \mathrm{mL}^{-1}$ of MTT was added to each well. Incubation was continued at room temperature for 4-5 h. The content of each well was removed, and 100 $\mu \mathrm{L}$ of isopropanol containing $5 \% 1 \mathrm{~mol} \mathrm{~L}^{-1} \mathrm{HCl}$ was added to extract the dye. After $12 \mathrm{~h}$ of incubation at room temperature, the optical density (OD) was measured with a microplate reader at $570 \mathrm{~nm}$.

\section{Results and Discussion}

\section{1. Synthesis of the complexes}

Complex 1 was prepared by the reaction of 4-fluoro-2-[(pyridin-2-ylmethylimino)methyl]phenol, zinc acetate and sodium azide in methanol, and complex 2 was prepared by the reaction of 4-fluoro-2-((2-(hydroxymethyl)phenylimino)methyl)phenol and zinc acetate in methanol. When compared with the zinc complexes with similar Schiff base ligands but different zinc salts, ${ }^{14}$ we found that the acetate and azide ligands are interesting bridging groups, which are readily participate in the construction of polynuclear complexes.

\section{2. Crystal Structure Description of Complex 1}

The molecular structure of complex $\mathbf{1}$ is shown in Fig. 1. Selected bond lengths and angles are listed in Table 2. The complex is a phenolate oxygen, nitrate, and end-on azide co-bridged tetranuclear zinc(II) species, with a crystallographic inversion center symmetry. The inversion center is located at the midpoint of the $\mathrm{Zn} 2$ and $\mathrm{Zn} 2 \mathrm{~A}$ atoms (symmetry code for A: $-x, 1-y, 1-z$ ). Zn2 forms distances of 3.160(1) and 3.353(1) $\AA$, respectively, with $\mathrm{Zn} 1$ and $\mathrm{Zn} 2 \mathrm{~A}$. All the zinc atoms are penta-coordinated in trigonal bipyramidal geometry. For the outer zinc atoms, $\mathrm{Zn} 1$ and $\mathrm{Zn} 1 \mathrm{~A}$, the equatorial plane is defined by the imino nitrogen (N1) of the Schiff base ligand, and two acetate oxygen $(\mathrm{O} 3, \mathrm{O} 5)$, and the axial positions are defined by the phenolate oxygen $(\mathrm{O} 1)$ and pyridine nitrogen (N2) of the Schiff base ligand. For the inner zinc atoms, $\mathrm{Zn} 2$ and $\mathrm{Zn} 2 \mathrm{~A}$, the equatorial plane is defined by the phenolate oxygen (O1), one acetate oxygen (O4), and one azide nitrogen $(\mathrm{N} 3 \mathrm{~A})$, and the axial positions are defined by one acetate oxygen (O2) and one azide nitrogen (N3). The trigonal bipyramidal coordination is distorted, which can be observed from the bond angles related to the zinc atoms. The bond angles of the equatorial planes range from $112.70(8)$ to $125.55(8)^{\circ}$ for $\mathrm{Zn1}$ and from $108.97(7)$ to $131.25(9)^{\circ}$ for $\mathrm{Zn} 2$. In addition, the perpendicular angles are 166.31(7) ${ }^{\circ}$ for $\mathrm{Zn} 1$ and 169.41(7) ${ }^{\circ}$ for $\mathrm{Zn} 2$. The coordinate bond lengths are also deviate from the ideal values of trigonal bipyramidal geometry, but they are within normal values as compared to other Schiff base zinc(II) complexes. ${ }^{15} \mathrm{Zn} 1$ and $\mathrm{Zn} 2$ atoms deviate from the best coordination planes defined by the equatorial donor atoms by 0.120(1) Å and 0.155(1) A, respectively.

The question arises as to whether the coordination polyhedra around the five-coordinated zinc atoms can be described as distorted square pyramid or distorted trigonal bipyramid. Further information can be obtained by determining the structural index $\tau$ which represents the relative amount of trigonality (square pyramid, $\tau=0$; trigonal bipyramid, $\tau=1) ; \tau=(\beta-\alpha) / 60^{\circ}, \alpha$ and $\beta$ being the two largest angles around the central atom. ${ }^{16}$ The values of $\tau$ are 0.68 for $\mathrm{Zn} 1$ and 0.636 for $\mathrm{Zn} 2$. Therefore, the coordination geometries of the zinc atoms in the complex are best described as severely distorted trigonal bipyramids, instead of square pyramids.

In the crystal structure of the complex, the tetranuclear zinc complex molecules are linked through C8H8A...O3 hydrogen bonds (Table 3), to form 1D chains along the $b$ axis (Fig. 2).

\section{3. Crystal Structure Description of Complex 2}

The molecular structure of complex 2 is shown in Fig. 3. Selected bond lengths and angles are listed in Table 2. The complex is a hydroxyl oxygen bridged tetranuclear zinc(II) species. The distances among the $\mathrm{Zn}$ atoms are in the range 3.005(1)-3.168(1) $\AA$. The $\mathrm{Zn} 1$ and $\mathrm{Zn} 2$ atoms are penta-coordinated in square pyramidal geometry, as evidenced by the $\tau$ values of 0.38 for $\mathrm{Zn} 1$ and 0.40 for $\mathrm{Zn} 2$. The basal planes are defined by the phenolate oxygen (O5 for $\mathrm{Zn} 1$, O3 for Zn2), imino nitrogen (N3 for Zn1, N2 for $\mathrm{Zn} 2$ ) and hydroxyl oxygen (O6 for $\mathrm{Zn} 1, \mathrm{O} 4$ for $\mathrm{Zn} 2$ ) of one Schiff base ligand, and the hydroxyl oxygen (O8 for $\mathrm{Zn} 1, \mathrm{O} 2$ for Zn2) of another Schiff base ligand. The apical positions are occupied by the hydroxyl oxygen (O4 for $\mathrm{Zn} 1, \mathrm{O} 8$ for $\mathrm{Zn} 2)$. The $\mathrm{Zn} 1$ and $\mathrm{Zn} 2$ atoms deviate from the basal planes by $0.415(2)$ and $0.353(2) \AA$, respectively. The square pyramidal coordination is distorted, which can 
Table 2. Selected bond lengths $(\AA)$ and angles $\left(^{\circ}\right)$ for the complexes

\begin{tabular}{|c|c|c|c|}
\hline \multicolumn{4}{|l|}{1} \\
\hline $\mathrm{Zn} 1-\mathrm{O} 1$ & $2.0484(16)$ & Zn1-N1 & $2.055(2)$ \\
\hline $\mathrm{Zn} 1-\mathrm{O} 3$ & $1.9866(17)$ & $\mathrm{Zn} 1-\mathrm{N} 2$ & $2.1321(19)$ \\
\hline $\mathrm{Zn} 1-\mathrm{O} 5$ & $1.9915(18)$ & $\mathrm{Zn} 2-\mathrm{O} 1$ & $1.9864(17)$ \\
\hline $\mathrm{Zn} 2-\mathrm{O} 4$ & $1.9707(19)$ & $\mathrm{Zn} 2-\mathrm{N} 3 \mathrm{~A}$ & $1.986(2)$ \\
\hline $\mathrm{Zn} 2-\mathrm{O} 2$ & $2.0707(19)$ & $\mathrm{Zn} 2-\mathrm{N} 3$ & $2.290(2)$ \\
\hline $\mathrm{O} 3-\mathrm{Zn} 1-\mathrm{O} 5$ & $112.70(8)$ & $\mathrm{O} 3-\mathrm{Zn} 1-\mathrm{O} 1$ & $95.44(7)$ \\
\hline $\mathrm{O} 5-\mathrm{Zn} 1-\mathrm{O} 1$ & $97.75(7)$ & $\mathrm{O} 3-\mathrm{Zn} 1-\mathrm{N} 1$ & $125.55(8)$ \\
\hline O5-Zn1-N1 & $120.69(8)$ & $\mathrm{O} 1-\mathrm{Zn} 1-\mathrm{N} 1$ & $87.67(7)$ \\
\hline $\mathrm{O} 3-\mathrm{Zn} 1-\mathrm{N} 2$ & $91.47(7)$ & $\mathrm{O} 5-\mathrm{Zn} 1-\mathrm{N} 2$ & $90.43(7)$ \\
\hline $\mathrm{O} 1-\mathrm{Zn} 1-\mathrm{N} 2$ & $166.31(7)$ & $\mathrm{N} 1-\mathrm{Zn} 1-\mathrm{N} 2$ & $78.70(8)$ \\
\hline $\mathrm{O} 4-\mathrm{Zn} 2-\mathrm{O} 1$ & $108.97(7)$ & $\mathrm{O} 4-\mathrm{Zn} 2-\mathrm{N} 3 \mathrm{~A}$ & 117.91(9) \\
\hline $\mathrm{O} 1-\mathrm{Zn} 2-\mathrm{N} 3 \mathrm{~A}$ & $131.25(9)$ & $\mathrm{O} 4-\mathrm{Zn} 2-\mathrm{O} 2$ & $99.14(8)$ \\
\hline $\mathrm{O} 1-\mathrm{Zn} 2-\mathrm{O} 2$ & $92.32(7)$ & $\mathrm{N} 3 \mathrm{~A}-\mathrm{Zn} 2-\mathrm{O} 2$ & $92.81(8)$ \\
\hline $\mathrm{O} 4-\mathrm{Zn} 2-\mathrm{N} 3$ & $88.25(9)$ & $\mathrm{O} 1-\mathrm{Zn} 2-\mathrm{N} 3$ & $92.42(8)$ \\
\hline $\mathrm{N} 3-\mathrm{Zn} 2-\mathrm{N} 3 \mathrm{~A}$ & $76.96(9)$ & $\mathrm{O} 2-\mathrm{Zn} 2-\mathrm{N} 3$ & $169.41(7)$ \\
\hline \multicolumn{4}{|l|}{2} \\
\hline $\mathrm{Zn} 1-\mathrm{O} 5$ & $1.942(6)$ & $\mathrm{Zn} 1-\mathrm{O} 4$ & $2.021(5)$ \\
\hline Zn1-N3 & $2.054(8)$ & Zn1-O6 & $2.061(5)$ \\
\hline $\mathrm{Zn} 1-\mathrm{O} 8$ & $2.156(5)$ & $\mathrm{Zn} 2-\mathrm{O} 3$ & $1.987(6)$ \\
\hline $\mathrm{Zn} 2-\mathrm{O} 8$ & $2.003(5)$ & $\mathrm{Zn} 2-\mathrm{N} 2$ & $2.021(7)$ \\
\hline $\mathrm{Zn} 2-\mathrm{O} 2$ & $2.069(5)$ & $\mathrm{Zn} 2-\mathrm{O} 4$ & $2.118(5)$ \\
\hline $\mathrm{Zn} 3-\mathrm{O} 7$ & $1.968(5)$ & $\mathrm{Zn} 3-\mathrm{O} 8$ & $2.086(5)$ \\
\hline $\mathrm{Zn} 3-\mathrm{N} 4$ & $2.094(7)$ & $\mathrm{Zn} 3-\mathrm{O} 2$ & $2.112(5)$ \\
\hline Zn3-O6 & $2.133(5)$ & Zn3-O9 & $2.255(6)$ \\
\hline $\mathrm{Zn} 4-\mathrm{O} 1$ & $1.943(6)$ & $\mathrm{Zn} 4-\mathrm{O} 2$ & $2.083(5)$ \\
\hline Zn4-N1 & $2.119(6)$ & Zn4-O6 & $2.119(5)$ \\
\hline $\mathrm{Zn} 4-\mathrm{O} 4$ & $2.173(5)$ & $\mathrm{Zn} 4-\mathrm{O} 10$ & $2.265(6)$ \\
\hline O5-Zn1-N3 & $92.2(3)$ & O5-Zn1-O6 & $167.0(2)$ \\
\hline N3-Zn1-O6 & $89.9(3)$ & $\mathrm{O} 5-\mathrm{Zn} 1-\mathrm{O} 8$ & $91.4(2)$ \\
\hline N3-Zn1-O8 & $144.4(3)$ & O6-Zn1-O8 & $79.58(19)$ \\
\hline $\mathrm{O} 4-\mathrm{Zn} 1-\mathrm{O} 8$ & $84.1(2)$ & $\mathrm{O} 4-\mathrm{Zn} 1-\mathrm{O} 6$ & $84.6(2)$ \\
\hline $\mathrm{O} 5-\mathrm{Zn} 1-\mathrm{O} 4$ & $103.8(2)$ & $\mathrm{O} 4-\mathrm{Zn} 1-\mathrm{N} 3$ & $129.1(3)$ \\
\hline $\mathrm{O} 3-\mathrm{Zn} 2-\mathrm{O} 8$ & $101.2(2)$ & $\mathrm{O} 8-\mathrm{Zn} 2-\mathrm{N} 2$ & $123.4(2)$ \\
\hline $\mathrm{O} 8-\mathrm{Zn} 2-\mathrm{O} 2$ & $87.20(19)$ & $\mathrm{O} 8-\mathrm{Zn} 2-\mathrm{O} 4$ & $85.5(2)$ \\
\hline $\mathrm{O} 3-\mathrm{Zn} 2-\mathrm{N} 2$ & $91.0(3)$ & $\mathrm{O} 3-\mathrm{Zn} 2-\mathrm{O} 2$ & $93.6(2)$ \\
\hline $\mathrm{N} 2-\mathrm{Zn} 2-\mathrm{O} 2$ & $147.5(2)$ & $\mathrm{O} 3-\mathrm{Zn} 2-\mathrm{O} 4$ & $170.9(2)$ \\
\hline $\mathrm{N} 2-\mathrm{Zn} 2-\mathrm{O} 4$ & $90.5(3)$ & $\mathrm{O} 2-\mathrm{Zn} 2-\mathrm{O} 4$ & $80.4(2)$ \\
\hline $\mathrm{O} 7-\mathrm{Zn} 3-\mathrm{O} 8$ & $176.1(2)$ & $\mathrm{O} 7-\mathrm{Zn} 3-\mathrm{N} 4$ & $89.2(3)$ \\
\hline $\mathrm{O} 8-\mathrm{Zn} 3-\mathrm{N} 4$ & $91.2(2)$ & $\mathrm{O} 7-\mathrm{Zn} 3-\mathrm{O} 2$ & $95.8(2)$ \\
\hline $\mathrm{O} 8-\mathrm{Zn} 3-\mathrm{O} 2$ & 83.95(19) & $\mathrm{N} 4-\mathrm{Zn} 3-\mathrm{O} 2$ & $174.9(2)$ \\
\hline O7-Zn3-O6 & $96.5(2)$ & $\mathrm{O} 8-\mathrm{Zn} 3-\mathrm{O} 6$ & $79.6(2)$ \\
\hline N4-Zn3-O6 & $99.7(3)$ & $\mathrm{O} 2-\mathrm{Zn} 3-\mathrm{O} 6$ & $81.1(2)$ \\
\hline O7-Zn3-O9 & $95.2(3)$ & $\mathrm{O} 8-\mathrm{Zn} 3-\mathrm{O} 9$ & $88.7(2)$ \\
\hline N4-Zn3-O9 & $91.2(3)$ & $\mathrm{O} 2-\mathrm{Zn} 3-\mathrm{O} 9$ & $87.1(2)$ \\
\hline O6-Zn3-O9 & $164.1(2)$ & $\mathrm{O} 1-\mathrm{Zn} 4-\mathrm{O} 2$ & $177.2(2)$ \\
\hline $\mathrm{O} 1-\mathrm{Zn} 4-\mathrm{N} 1$ & $88.9(3)$ & $\mathrm{O} 2-\mathrm{Zn} 4-\mathrm{N} 1$ & $88.5(2)$ \\
\hline $\mathrm{O} 1-\mathrm{Zn} 4-\mathrm{O} 6$ & $100.5(2)$ & $\mathrm{O} 2-\mathrm{Zn} 4-\mathrm{O} 6$ & $82.1(2)$ \\
\hline N1-Zn4-O6 & $170.6(3)$ & $\mathrm{O} 1-\mathrm{Zn} 4-\mathrm{O} 4$ & $100.4(2)$ \\
\hline $\mathrm{O} 2-\mathrm{Zn} 4-\mathrm{O} 4$ & $78.8(2)$ & $\mathrm{N} 1-\mathrm{Zn} 4-\mathrm{O} 4$ & $99.5(2)$ \\
\hline O6-Zn4-O4 & $79.61(19)$ & $\mathrm{O} 1-\mathrm{Zn} 4-\mathrm{O} 10$ & $95.9(3)$ \\
\hline $\mathrm{O} 2-\mathrm{Zn} 4-\mathrm{O} 10$ & $85.4(2)$ & $\mathrm{N} 1-\mathrm{Zn} 4-\mathrm{O} 10$ & $92.7(2)$ \\
\hline $\mathrm{O} 6-\mathrm{Zn} 4-\mathrm{O} 10$ & $85.7(2)$ & $\mathrm{O} 4-\mathrm{Zn} 4-\mathrm{O} 10$ & $159.8(2)$ \\
\hline
\end{tabular}

Symmetry code for A: $-x, 1-y, 1-z$. be observed from the bond angles related to the zinc atoms. The cis and trans bond angles of the basal planes range from $79.58(19)$ to $92.2(3)^{\circ}$ and $84.1(2)$ to $129.1(3)^{\circ}$ for $\mathrm{Zn} 1$, and from $80.4(2)$ to $93.6(2)^{\circ}$ and $85.2(2)$ to 123.4(2) $)^{\circ}$ for $\mathrm{Zn} 2$.

The Zn3 and Zn4 atoms are hexacoordinated in octahedral geometry. The equatorial planes are defined by the phenolate oxygen (O7 for $\mathrm{Zn} 3$, O1 for $\mathrm{Zn} 4$ ), imino nitrogen (N4 for Zn1, N1 for Zn4) and hydroxyl oxygen (O8 for $\mathrm{Zn} 1, \mathrm{O} 2$ for $\mathrm{Zn} 4)$ of one Schiff base ligand, and the hydroxyl oxygen (O2 for $\mathrm{Zn} 1$, O6 for $\mathrm{Zn} 4)$ of another Schiff base ligand. The axial positions are occupied by the hydroxyl oxygen (O6 for $\mathrm{Zn} 1, \mathrm{O} 4$ for $\mathrm{Zn} 4$ ) and the water oxygen (O9) for $\mathrm{Zn} 3$ or ethanol oxygen (O10) for $\mathrm{Zn} 4$. The $\mathrm{Zn} 3$ and $\mathrm{Zn} 4$ atoms deviate from the basal planes by 0.021 (2) and 0.003(2) $\AA$, respectively. The octahedral coordination is distorted, which can be observed from the bond angles related to the zinc atoms. The cis and trans bond angles of the equatorial planes range from 93.95(19) to $95.8(2)^{\circ}$ and $174.9(2)$ to $176.1(2)^{\circ}$ for $\mathrm{Zn} 3$, and from 82.1(2) to $100.5(2)^{\circ}$ and $170.6(3)$ to $177.2(2)^{\circ}$ for $\mathrm{Zn} 4$. In addition, the perpendicular angles are 164.1(2) ${ }^{\circ}$ for $\mathrm{Zn} 3$ and $159.8(2)^{\circ}$ for $\mathrm{Zn} 4$. The coordinate bond lengths are within normal values as compared to other Schiff base zinc(II) complexes. ${ }^{15}$

In the crystal structure of the complex, the tetranuclear zinc complex molecules are linked through $\mathrm{C}-\mathrm{H}$... F hydrogen bonds (Table 3), to form a 3D network (Fig. 4).

Table 3. Hydrogen bond distances $(\AA)$ and bond angles $\left({ }^{\circ}\right)$ for the complexes

\begin{tabular}{|c|c|c|c|c|}
\hline$D-\mathrm{H} \cdots A$ & $d(D-\mathrm{H})$ & $d(\mathbf{H} \cdots A)$ & $d(D \cdots A)$ & $\begin{array}{r}\text { Angle } \\
(D-\mathrm{H} \cdots A)\end{array}$ \\
\hline \multicolumn{5}{|l|}{1} \\
\hline $\begin{array}{l}\mathrm{O} 8-\mathrm{H} 8 \mathrm{~A} \cdots \mathrm{O}^{\mathrm{i}} \\
2\end{array}$ & 0.97 & 2.54 & $3.381(2)$ & $145(3)$ \\
\hline $\mathrm{C} 21-\mathrm{H} 21 \cdots \mathrm{F} 1^{\mathrm{ii}}$ & 0.93 & 2.55 & $3.419(5)$ & $156(6)$ \\
\hline $\mathrm{C} 38-\mathrm{H} 38 \cdots \mathrm{F} 4^{\mathrm{iii}}$ & 0.93 & 2.55 & $3.186(5)$ & $126(6)$ \\
\hline $\mathrm{C} 47-\mathrm{H} 47 \cdots \mathrm{F} 2^{\mathrm{iv}}$ & 0.93 & 2.47 & $3313(5)$ & $150(6)$ \\
\hline
\end{tabular}

Symmetry codes: i: $-x, 2-y,-z$; ii: $-x, 1-y,-z$; iii: $-1+x, y, z$; iv: 1 $-x, 1-y,-z$.

\section{3. IR and UV-Vis Spectra}

In the IR spectra of complex $\mathbf{1}$, the strong absorption at $2082 \mathrm{~cm}^{-1}$ is due to the vibration of the azide ligand. The intense absorption at $1622 \mathrm{~cm}^{-1}$ for $\mathrm{HL}^{1}, 1626 \mathrm{~cm}^{-1}$ for $\mathrm{H}_{2} \mathrm{~L}^{2}, 1598 \mathrm{~cm}^{-1}$ for 1 and $1609 \mathrm{~cm}^{-1}$ for 2 is assigned to the azomethine groups, $v(\mathrm{C}=\mathrm{N}) .{ }^{17}$ The bands undergoe negative shift of $17 \mathrm{~cm}^{-1}$ for 1 and $13 \mathrm{~cm}^{-1}$ for 2 when compared to the free Schiff bases, which can be attributed to donation of the azomethine nitrogen atom lone pair to the $\mathrm{Zn}$ atoms. This conclusion is further supported by the presence of weak bands at low wave numbers, which can 


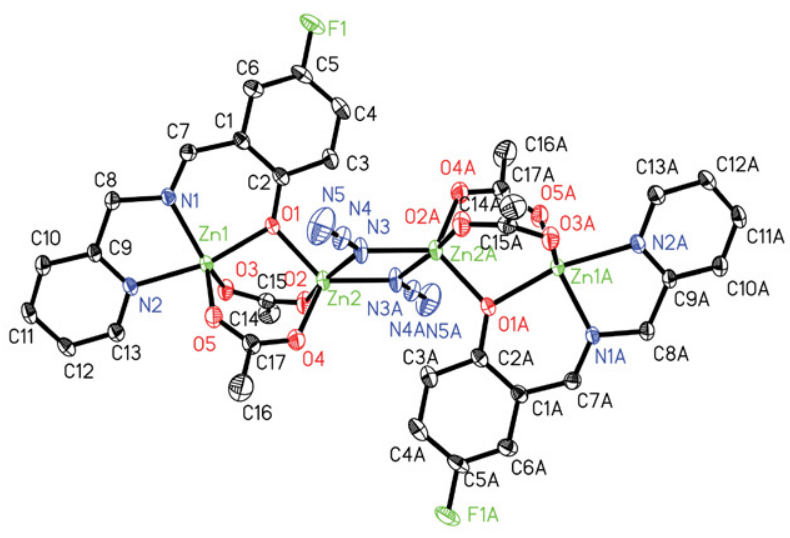

Fig. 1. ORTEP diagram of complex 1 with $30 \%$ thermal ellipsoids for all non-hydrogen atoms. Hydrogen atoms are omitted for clarity. Atoms with the suffix A are related to the operate position $-x, 1-y$, $1-z$.

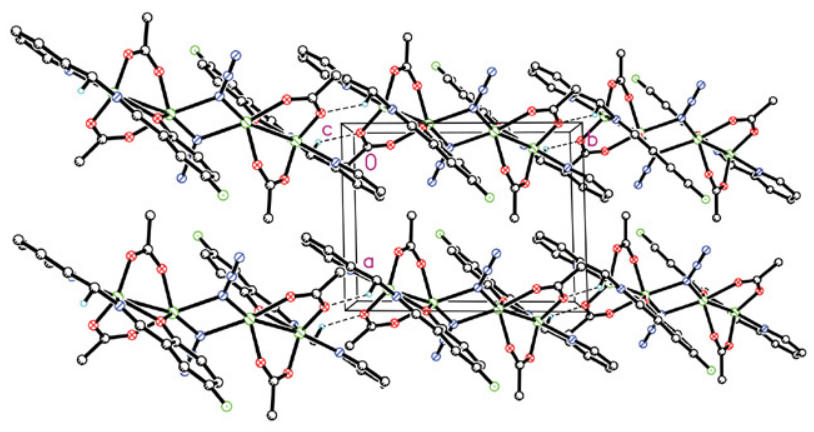

Fig. 2. Hydrogen bond (dashed lines) linked 1D chains of complex 1 , viewed along the $c$ axis.

be assigned to $v(\mathrm{Zn}-\mathrm{N})$ and $v(\mathrm{Zn}-\mathrm{O})$. The phenolic $v(\mathrm{C}-\mathrm{O})$ appears as a medium band at $1213 \mathrm{~cm}^{-1}$ for 1 and 1241 $\mathrm{cm}^{-1}$ for 2 .

\section{4. Antibacterial Activity}

The complexes and the free Schiff bases were screened for antibacterial property against three Gram-positive bacterial strains (B. subtilis, S. aureus, and St. faecalis) and three Gram-negative bacterial strains (E. coli, P. aeruginosa,

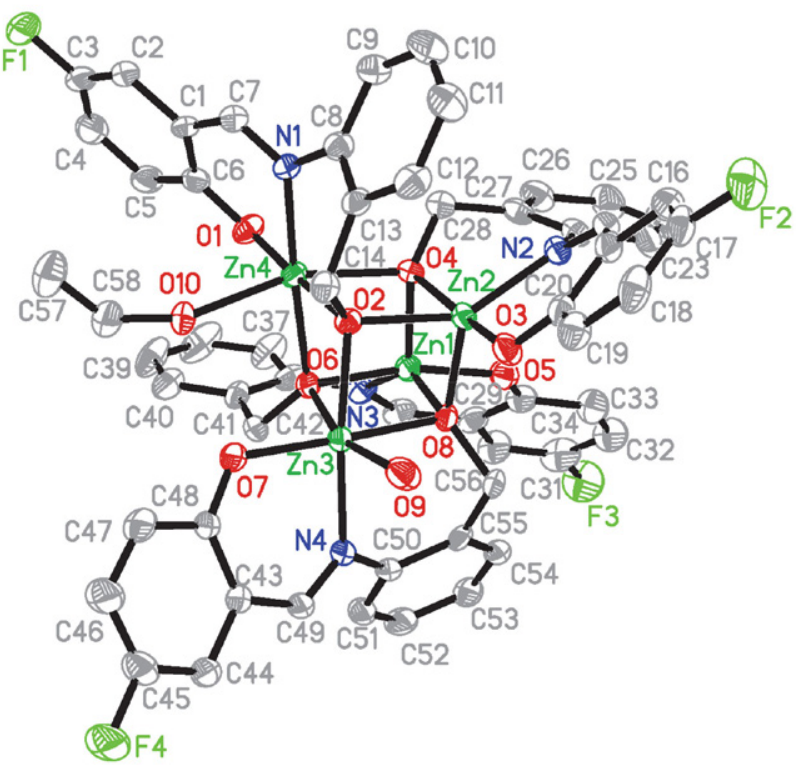

Fig. 3. ORTEP diagram of complex 2 with $30 \%$ thermal ellipsoids for all non-hydrogen atoms. Hydrogen atoms are omitted for clarity.

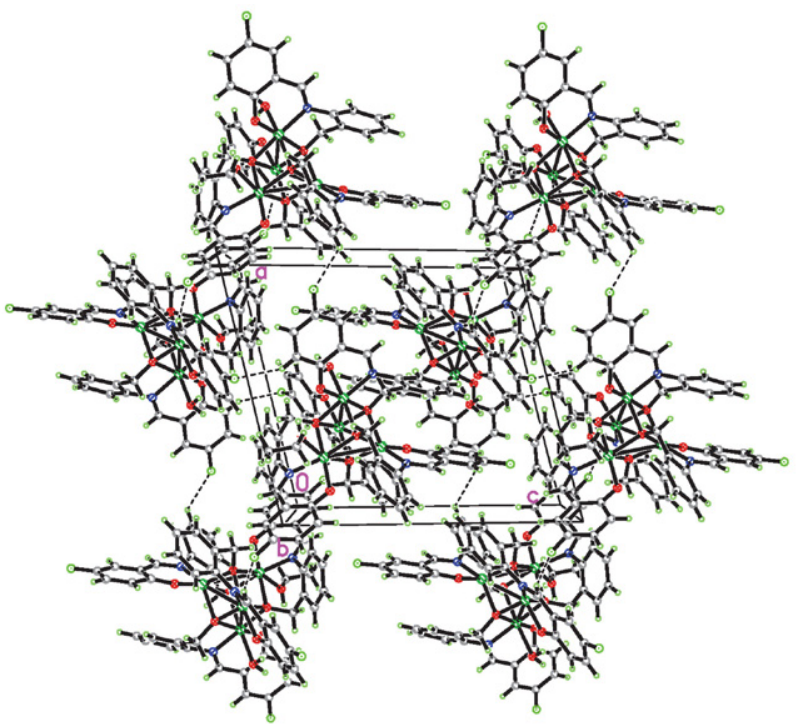

Fig. 4. Hydrogen bond (dashed lines) linked 3D network of complex 2 , viewed along the $b$ axis.

Table 4. MICs ( $\mu \mathrm{g} \mathrm{mL}^{-1}$ ) of the compounds and related materials

\begin{tabular}{|c|c|c|c|c|c|c|}
\hline \multirow{2}{*}{$\begin{array}{l}\text { Tested } \\
\text { material }\end{array}$} & \multicolumn{3}{|c|}{ Gram positive } & \multicolumn{3}{|c|}{ Gram negative } \\
\hline & B. subtilis & S. aureus & St. faecalis & P. aeruginosa & E. coli & E. cloacae \\
\hline 1 & 0.39 & 6.25 & 3.12 & 25 & 0.78 & $>50$ \\
\hline 2 & 0.78 & 3.12 & 6.25 & 25 & 3.12 & $>50$ \\
\hline $\mathrm{HL}^{1}$ & 1.56 & 12.5 & 12.5 & $>50$ & 3.12 & $>50$ \\
\hline $\mathrm{H}_{2} \mathrm{~L}^{2}$ & 3.12 & 6.25 & 12.5 & $>50$ & 6.25 & $>50$ \\
\hline $\mathrm{NaN}_{3}$ & 25 & $>50$ & $>50$ & $>50$ & 25 & $>50$ \\
\hline Penicillin & 1.56 & 1.56 & 1.56 & 6.25 & 6.25 & 3.12 \\
\hline Kanamycin & 0.39 & 1.56 & 3.12 & 3.12 & 3.12 & 1.56 \\
\hline
\end{tabular}


and E. cloacae) by MTT method. The MICs of the compounds against the bacteria are presented in Table 4. Penicillin and Kanamycin were tested as reference drugs. The complexes show strong activities against the Gram positive bacteria B. subtilis, S. aureus, St. faecalis, and the Gram negative bacteria $E$. coli, medium activity against the Gram negative bacteria $P$. aeruginosa, and no activity against $E$. cloacae. The free Schiff bases show strong activity against the Gram positive bacteria B. subtilis and the Gram negative bacteria $E$. coli, medium activity against $S$. aureus and St. faecalis, and no activity against $P$. aeruginosa and E. cloacae. In general, the antibacterial activities of the complexes are better than the free Schiff bases. The two complexes have higher activity than the vanadium complexes we reported previously, ${ }^{18}$ and the zinc, manganese, cobalt and cadmium complexes with hydrazone ligands. ${ }^{19}$

\section{Conclusion}

Two new tetranuclear zinc(II) complexes with fluoro-containing Schiff base ligands have been prepared and structurally characterized. The $\mathrm{Zn}$ atoms are in trigonal bipyramidal, square pyramidal and octahedral coordination. The complexes show strong activities against the Gram positive bacteria B. subtilis, S. aureus, St. faecalis, and the Gram negative bacteria E. coli, and medium activity against the Gram negative bacteria $P$. aeruginosa. The antibacterial assay of the free Schiff bases and the complexes indicate that they are potential antibacterial agents for B. subtilis and E. coli.

\section{Supplementary Material}

CCDC 967151 (1) and 2063585 (2) contain the supplementary crystallographic data for this paper. These data can be obtained free of charge at http://www.ccdc.cam. ac.uk/const/retrieving.html or from the Cambridge Crystallographic Data Centre (CCDC), 12 Union Road, Cambridge CB2 1EZ, UK; fax: +44(0)1223-336033 or e-mail: deposit@ccdc.cam.ac.uk.

\section{Acknowledgments}

Project supported by the Henan Province Universities and Colleges Funded Scheme (21A530010).

\section{References}

1. (a) A. Lupo, E. Cesaro, G. Montano, D. Zurlo, P. Izzo, P. Costanzo, Curr. Genomics 2013, 14, 268;

DOI:10.2174/13892029113149990002

(b) L. P. Huang, S. Tepaamorndech, Mol. Aspects Med. 2013,

34, 548; DOI:10.1016/j.mam.2012.05.008 (c) S. Tabassum, A. Asim, F. Arjmand, M. Afzal, V. Bagchi, Eur. J. Med. Chem. 2012, 58, 308.

DOI:10.1016/j.ejmech.2012.09.051

2. E. Roscioli, R. Hamon, S. Lester, C. Murgia, J. Grant, P. Zalewski, Biometals 2013, 26, 205.

DOI:10.1007/s10534-013-9618-2

3. K. L. Cooper, B. S. King, M. M. Sandoval, K. J. Liu, L. G. Hudson, Toxicol. Appl. Pharm. 2013, 269, 81.

DOI:10.1016/j.taap.2013.03.008

4. (a) Z. You, H. Yu, Z. Li, W. Zhai, Y. Jiang, A. Li, S. Guo, K. Li, C. Lv, C. Zhang, Inorg. Chim. Acta 2018, 480, 120;

DOI:10.1016/j.ica.2018.05.020

(b) Y.-T. Li, J.-W. Dong, Y. Lu, Y.-T. Gu, C.-N. Shang, F.-Y. Liu, Y. Xin, C.-L. Jing, Z.-L. You, Chinese J. Inorg. Chem. 2018, 34, 1192;

(c) J. Wang, D. Qu, J.-X. Lei, Z.-L. You, J. Coord. Chem. 2017, 70, 544. DOI:10.1080/00958972.2016.1262538

5. (a) V. C. D. Silveira, J. S. Luz, C. C. Oliveira, I. Graziani, M. R. Ciriolo, A. M. da Costa Ferreira, J. Inorg. Biochem. 2008, 102, 1090; DOI:10.1016/j.jinorgbio.2007.12.033

(b) C. Liang, J. Xia, D. Lei, X. Li, Q. Yao, J. Gao, Eur. J. Med. Chem. 2014, 74, 742. DOI:10.1016/j.ejmech.2013.04.040

6. (a) R. M. Ramadan, A. K. Abu Al-Nasr, A. F. Noureldeen, Spectrochim. Acta A Mol Bio. 2014, 132, 417;

DOI:10.1016/j.saa.2014.04.151

(b) J. R. Anacona, N. Noriega, J. Camus, Spectrochim. Acta A Mol Bio. 2015, 137, 16. DOI:10.1016/j.saa.2014.07.091

7. (a) G. Saravanan, T. P. Selvam, V. Alagarsamy, S. Kunjiappan, S. D. Joshi, M. Indhumathy, P. D. Kumar, Drug Res. 2018, 68, 250; DOI:10.1055/s-0043-120198

(b) M. Patil, R. Hunoor, K. Gudasi, Eur. J. Med. Chem. 2010, 45, 2981. DOI:10.1016/j.ejmech.2010.03.025

8. (a) M. Durgun, H. Trukmen, M. Ceruso, C. T. Supuran, Bioorg. Med. Chem. Lett. 2015, 25, 2377;

DOI:10.1016/j.bmcl.2015.04.007

(b) D. H. Shi, Z. L. You, Russ. J. Coord. Chem. 2010, 36, 535. DOI:10.1134/S1070328410070109

9. (a) M. Gopalakrishnan, J. Thanusu, V. Kanagarajan, R. Govindaraju, J. Enzym. Inhib. Med. Chem. 2009, 24, 52;

(b) L. Shi, H.-M. Ge, S.-H. Tan, H.-Q. Li, Y.-C. Song, H.-L. Zhu, R.-X. Tan, Eur. J. Med. Chem. 2007, 42, 558.

DOI:10.1016/j.ejmech.2006.11.010

10. (a) N. P. Rai, V. K. Narayanaswamy, T. Govender, B. K. Manuprasad, S. Shashikanth, P. N. Arunachalam, Eur. J. Med. Chem. 2010, 45, 2677;

(b) N. P. Rai, V. K. Narayanaswamy, S. Shashikanth, P. N. Arunachalam, Eur. J. Med. Chem. 2009, 44, 4522.

11. (a) M. Fleck, M. Layek, R. Saha, D. Bandyopadhyay, Transition Met. Chem. 2013, 38, 715;

DOI:10.1007/s11243-013-9741-5

(b) A. Cingolani, S. Galli, N. Masciocchi, L. Pandolfo, C. Pettinari, A. Sironi, Dalton Trans. 2006, 20, 2479; DOI:10.1039/b515630k

(c) F.-S. Guo, J.-D. Leng, J.-L. Liu, Z.-S. Meng, M.-L. Tong, Inorg. Chem. 2012, 51, 405; DOI:10.1021/ic2018314

(d) S. Mukherjee, P. S. Mukherjee, Dalton Trans. 2013, 42, 
4019; DOI:10.1039/c2dt32802j

(e) R. Biswas, S. Mukherjee, P. Kar, A. Ghosh, Inorg. Chem. 2012, 51, 8150. DOI:10.1021/ic300547w

12. G.M. Sheldrick, Acta Crystallogr. 2008, A64, 112. DOI:10.1107/S0108767307043930

13. J. Meletiadis, J. Meis, J. W. Mouton, J. P. Donnelly, P. E. Verweij, J. Clin. Microbiol. 2000, 38, 2949.

14. (a) A. Erxleben, Inorg. Chem. 2001, 40, 208;

DOI:10.1021/ic000600z

(b) H.-R. Wen, Y. Wang, J.-L. Chen, Y.-Z. Tang, J.-S. Liao, C.M. Liu, Inorg. Chem. Commun. 2012, 20, 303;

DOI:10.1016/j.inoche.2012.03.036

(c) H. S. Jena, V. Manivannan, Inorg. Chim. Acta 2013, 394, 210. DOI:10.1016/j.ica.2012.06.041
15. (a) J. Gao, Y.-G. Liu, Y.-Q. Zhou, L. M. Boxer, F. R. Woolley, R. A. Zingaro, ChemBioChem 2007, 8, 332; DOI:10.1002/cbic.200600299

(b) S. Majumder, L. Mandal, S. Mohanta, Inorg. Chem. 2012, 51, 8739. DOI:10.1021/ic300412u

16. A. W. Addison, T. N. Rao, J. Reedijk, J. van Rijn, G. C. Verschoor, J. Chem. Soc. Dalton Trans. 1984, 7, 1349.

DOI:10.1039/DT9840001349

17. Y.-M. Zhou, X.-R. Ye, F.-B. Xin, X.-Q. Xin, Transition Met. Chem. 1999, 24, 118. DOI:10.1023/A:1006989707001

18. H.-Y. Qian, Acta Chim. Slov. 2019, 66, 995.

19. (a) L.-W. Xue, H.-J. Zhang, P.-P. Wang, Acta Chim. Slov. 2019, 66, 190; DOI:10.17344/acsi.2018.4773

(b) L.-H. Wang, X.-Y. Qiu, S.-J. Liu, Acta Chim. Slov. 2019, 66, 675; DOI:10.17344/acsi.2019.5117

(c) Y.-L. Sang, X.-S. Lin, W.-D. Sun, Acta Chim. Slov. 2020, 67, 581. DOI:10.17344/acsi.2019.5595

\section{Povzetek}

Sintetizirali smo dva nova štirijedrna cinkova(II) kompleksa, $\left[\mathrm{Zn}_{4}\left(\mathrm{~L}^{1}\right)_{2}\left(\mu_{2}-\eta^{1}: \eta^{1}-\mathrm{CH}_{3} \mathrm{COO}\right)_{4}\left(\mu_{1,1}-\mathrm{N}_{3}\right)_{2}\right] \quad(\mathbf{1})$ in $\left[\mathrm{Zn}_{4}\left(\mathrm{~L}^{2}\right)_{4}\left(\mathrm{CH}_{3} \mathrm{CH}_{2} \mathrm{OH}\right)\left(\mathrm{H}_{2} \mathrm{O}\right)\right](2)$, kjer sta $\mathrm{L}^{1}$ in $\mathrm{L}^{2}$ deprotonirani obliki 4-fluoro-2-((piridin-2-ilmetilimino)metil)fenola $\left(\mathrm{HL}^{1}\right)$ in 4-fluoro-2-((2-(hidroksimetil)fenilimino)metil)fenol $\left(\mathrm{H}_{2} \mathrm{~L}^{2}\right)$ ter ju okarakterizirali z elementno analizo, IR in UV-vis spektroskopijo ter rentgensko monokristalno analizo. Rentgenska strukturna analiza razkriva, da so razdalje med sosednjimi cinkovimi atomi 3.160(1)-3.353(1) A v 1 in 3.005(1)-3.168(1) ̊̊ v 2. Vsi cinkovi atomi v 1 so pentakoordinirani $\mathrm{z}$ trigonalno bipiramidalno geometrijo in $\mathrm{v} 2 \mathrm{~s}$ kvadratno piramidalno in oktaedrično geometrijo. Kompleksoma in Schiffovima bazama smo določili antibakterijsko aktivnost proti trem Gram-pozitivnim bakterijskim sevom (B. subtilis, S. aureus, in St. faecalis) in trem Gram-negativnim sevom (E. coli, P. aeruginosa, and E. cloacae) z MTT metodo.

Except when otherwise noted, articles in this journal are published under the terms and conditions of the Creative Commons Attribution 4.0 International License 